\title{
Integrated Use of Co-Compost with Lignite Fly Ash on Yield and Nutrient Uptake of Certain Crops
}

\author{
Angayarkanni, A ${ }^{1}$, M.V. Sriramachandrasekharan ${ }^{2}$, M. Salahuddin ${ }^{3}$, P. Poonkodi ${ }^{4}$ \\ 1,2,4 Department of Soil Science and Agricultural Chemistry, Faculty of Agriculture, Annamalai University, \\ Annamalainagar-608002 \\ ${ }^{3}$ Director, Ministry of Environment, Forest and Climate Change, New Delhi
}

\begin{abstract}
A field experiment was conducted to know the response of crops to combined application of co compost and lignite fly ash. Field experiments were conducted in experimental farm (rice and maize) and farmers holding (groundnut and brinjal) to study the response of certain crops to the application of co composts and lignite fly ash grown in clay loam and sandy clay loam soil, respectively. The treatment consisted of Dairy Farm Waste + Crop Residues, Pressmud+ Crop Residues, Dairy Farm Waste + Crop Residues + LFA @5 t ha-1, Dairy Farm Waste + Crop Residues + LFA @ 10 t ha-1, Dairy Farm Waste + Crop Residues + LFA @15 t ha-1, Pressmud + crop residues + LFA@5 t ha-1, Pressmud + crop residues + LFA @10 t ha-1and Pressmud + crop residues + LFA @ 15 t ha-1 .The grain and straw yield in rice and maize, pod and haulm yield in groundnut and fruit yield of brinjal were recorded during harvest. Differences in yield of crops between the treatments indicate significantly different effects on soil fertility and crop yield after long-term fertilization. The uptake of nutrients increased linearly with levels of LFA tried and it was higher when it was applied with co compost of pressmud and crop residue. The addition of co composts alone or with graded dose of lignite fly ash significantly improved the physical properties of the soil.
\end{abstract}

KEYWORDS: Co-compost, Crops LFA, Yield, Uptake.

\section{INTRODUCTION}

Applying compost can contribute to agricultural sustainability. Reuse of organic waste through composting is promoted as a primary measure to mitigate such environmental threats by developed nations (Pampuro et al., 2016). Adequate use of compost with proper management has been shown to have many advantages. These advantages include adding an array of nutrients to soils (Tejada et al., 2009), increasing SOM, improving water holding capacity and other physical properties of soil such as bulk density, penetration resistance and soil aggregation (Wells et al.,2000). Co-composting is an effective technique, which turns both on and off-farm wastes into a resource. The primary advantage of co-composting on-farm and off-farm wastes is to blend and balance the $\mathrm{C}$ : $\mathrm{N}$ ratio of the waste materials. Co-composting Dairy farm and crop residue wastes with clean organic agricultural and nonagricultural wastes offers a number of opportunities for farmers. It can generate revenue by converting livestock manure into a stable soil conditioner. The co-compost prepared can be effectively utilized for all crops along with fertilizers to improve the nutrient use efficiency Fly ash (FA) is a fine grey powder, produced by combusting coal in thermal power station, which was considered in previous times as a waste, is now used as a valuable resource in agriculture to improve texture, reduce acidic character of soil, enhance nutrient levels, increase water holding capacity and can be used against pests to protect vegetables. (Rautaray et al., 2003, Jala and Goyal, 2006). Fly ash is gaining importance in agriculture as it contains many nutrients, especially the secondary $(\mathrm{Ca}, \mathrm{Mg} \& \mathrm{~S})$ and the micronutrients $(\mathrm{Fe}, \mathrm{Mn}, \mathrm{Zn} \& \mathrm{Cu}$ ). Therefore, it may be used as nutrient source to plants and also to improve the physicochemical properties of soils. Adding fly ash and chemical fertilizers could influence the decomposition ability of organic materials, and thus, the released pattern of nutrients from organic materials could also change. Thus, a field experiment was conducted to know the response of crops to combined application of co compost and lignite fly ash.

\section{MATERIALS AND METHODS}

Field experiments were conducted in experimental farm (rice and maize) and farmers holding (groundnut and brinjal) to study the response of certain crops to the application of co composts and lignite fly ash grown in clay loam and sandy clay loam soil, respectively. The experimental soil was low in available nitrogen and medium in available phosphorus and potassium The 


\section{International Journal of Current Science Research and Review}

ISSN: 2581-8341

Volume 04 Issue 10 October 2021

DOI: 10.47191/ijcsrr/V4-i10-06, Impact Factor: 5.825

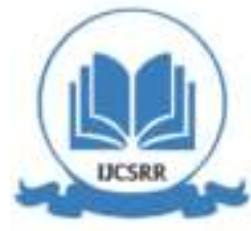

WWw.ijesrr.org

treatment consists of Dairy Farm Waste + Crop Residues, Pressmud+ Crop Residues, Dairy Farm Waste + Crop Residues + LFA @ $\mathrm{t} \mathrm{ha}^{-1}$, Dairy Farm Waste + Crop Residues + LFA@10 t ha ${ }^{-1}$, Dairy Farm Waste + Crop Residues + LFA@15 t ha ${ }^{-1}$, Pressmud + crop residues + LFA@5 t ha ${ }^{-1}$, Pressmud + crop residues + LFA @ $10 \mathrm{t} \mathrm{ha}^{-1}$, Pressmud + crop residues + LFA@15 t ha ${ }^{-1}$ and were laid out in RBD with three replications. The test crop tried were rice var ADT43, Maize var hybrid: P3502, groundnut var TMV 3 and Brinjal var Annamalai. All the crops received recommended dose of fertilizer viz., rice (150:50:50), maize (150:62.5:50), groundnut (17:34:54) and Brinjal (120:60:30) $\mathrm{N}, \mathrm{P}_{2} \mathrm{O}_{5}$ and $\mathrm{K}_{2} \mathrm{O} \mathrm{kg} \mathrm{ha}^{-1}$, respectively. The chemical composition of DFW and CR co compost was N-1.32\%, P-0.434\%, K-0.833\%, C-17.56 and C: N ratio- 13.3 and pressmud and crop residue co compost had N-1.50, P-0.596\%, K- 0.883\%, C- 16.04\% and C:N ratio- 10.7.The grain and straw yield in rice and maize, pod and haulm yield in groundnut and fruit yield of brinjal were recorded during harvest. The samples were analysed for nutrient content following standard procedure and their uptake was computed. The post-harvest soil samples were analysed for bulk density, moisture retentive capacity and water stable aggregates.

\section{RESULTS AND DISCUSSION}

\section{A. Yield of crops}

Addition of graded levels of lignite flyash either with co compost of dairy farm waste plus crop residue or with pressmud with crop residue registered significant response of crops

examined over co compost alone (table 1). The response of crops to combined application of lignite flyash with pressmud and crop residue was higher than that of combined addition of lignite fly ash with dairy farm waste and crop residue. The yield response due to conjoint application of LFA with dairy farm waste plus crop residue over dairy farm waste plus crop residue alone ranged from 725 to $1425 \mathrm{~kg} / \mathrm{ha}$ (rice), 550 to $1110 \mathrm{~kg} / \mathrm{ha}$ ( maize), 298 to $710 \mathrm{~kg} / \mathrm{ha}$ (groundnut) and 2.72 to $6.61 \mathrm{t} / \mathrm{ha}$ ( Brinjal). Similarly, the yield response due to conjoint application of LFA with pressmud with crop residue ranged from 950 to $1525 \mathrm{~kg} / \mathrm{ha}$ (rice), 500 to $1200 \mathrm{~kg} / \mathrm{ha}$ (maize), 300 to $725 \mathrm{~kg} / \mathrm{ha}$ (groundnut) and 5.10 to $8.81 \mathrm{t} / \mathrm{ha}$ (brinjal). The percent increase due to combined addition of LFA and co compost over co compost alone ranged 14 to 29 in grain and 11.4 to 23.3 in straw of rice, 10.9 to 26.1 in grain and 14.1 to 29 in straw of maize, 13.1 to $31.5 \mathrm{in}$ pod and 9.9 to 22.1 in haulm of groundnut and 14.1 to 43.9 in Brinjal (fig.1). The highest response of crops $\left(6775,8475 \mathrm{~kg} \mathrm{ha}^{-1}\right.$ in rice, $5800,9940 \mathrm{~kg} \mathrm{ha}^{-1}$ in maize, $3025,3882 \mathrm{~kg} \mathrm{ha}^{-1}$ in groundnut and $28.87 \mathrm{t}$ ha ${ }^{1}$ in Brinjal) was realized with application of LFA@15 $\mathrm{t} \mathrm{ha}^{-1}$ and co compost of pressmud with crop residue. It was comparable with LFA @ $10 \mathrm{t} \mathrm{ha}^{-1}$ with co compost of pressmud and crop residue. Compost is a stable humus-like product, which results from the biological decomposition of organic materials under controlled conditions. Compost helps retain moisture in the soil, provides crucial, slow-release nutrients to crops and can lead to long-term yield increases. Differences in yield of crops between the treatments indicate significantly different effects on soil fertility and crop yield after long-term different fertilization. Multiple benefits derived from compost using as fertilizer by increasing organic content and microbial activity (Scotti et al., 2015). The enhancement effect of compost may be resulted from a greater concentration of plant nutrients like $\mathrm{N}, \mathrm{P}, \mathrm{K}$, and $\mathrm{Mg}$ and a root reinforcement induced by compost (Donn et al., 2014 and Nadjet et al., 2014). Several researchers have reported the significance of compost in triggering and enhancing soil fertility via supplying nutrients for plant use (Gul et al., 2016; Irshad et al.,2014) resulting in higher yield of crops. The Co compost of crop residue and pressmud had lowest $\mathrm{CN}$ ratio besides higher organic carbon content and nutrient content compared to dairy farm waste and crop residue co compost which was reflected in obtaining maximum yield across the crops studied. The contribution of essential plant nutrients and the favourable physical environment in the soil treated with FA, would have facilitated the growth and yield of crops. The addition of Si through FA was reported to produce erect leaves that could account for a 100 percent increase in the photosynthesis of the canopy and consequently would have increased the yield. Not only the supply of nutrients but also the better utilization of nutrients made available on account of the complementary effect of compost and FA, favourable physical conditions, higher uptake of nutrients would have paved the way for realizing the full potentials of crops. In the present study, combined addition of co compost and LFA recorded higher nutrient uptake and physical properties. Further, the agronomic efficiency of crops due to lignite fly ash application with co compost of pressmud and crop residue was higher than with co compost of dairy farm waste and crop residue (fig.2) also supports higher response of crops to LFA application 


\section{International Journal of Current Science Research and Review}

ISSN: 2581-8341

Volume 04 Issue 10 October 2021

DOI: 10.47191/ijcsrr/V4-i10-06, Impact Factor: 5.825

\section{B. Nutrient uptake}

The uptake of nutrients by grain and straw in rice and maize, pod and haulm in groundnut and fruit in brinjal was significantly higher when fly ash at graded levels was applied with co compost compared to co compost alone. ( table2). The uptake of nutrients increased linearly with levels of LFA tried and it was higher when it was applied with co compost of pressmud and crop residue compared to co compost of dairy farm waste and crop residue. The highest uptake of nutrients irrespective of crops was recorded with conjoint application of LFA@ $15 \mathrm{t} \mathrm{ha}^{-1}$ with co compost of pressmud and crop residue and it was comparable with LFA@10 $\mathrm{t} \mathrm{ha}^{-1}$ with co compost of pressmud and crop residue. Increased nutrient uptake by crops by co compost application indicated high quality of organic matter which might have increased bioavailability of N, P K, S and Ca. The increased nutrient content has been attributed to the elemental contents of the composts, which improved the root growth and increased the nutrient uptake by plants (Aziz et al.,2006). Irshad et al. (2002) reported that increasing composted manure application profoundly increased the nutrients uptake by plants for better growth. Malhi (2012) reported that, application of organic manures favoured the uptake of N, K and S in wheat. Further increase in nutrient uptake on addition of lignite fly ash could be due to higher availability of nutrients in soil solution from direct supply of fly ash. Fly ash being a good source of silicon, silicon application enhanced nitrogen uptake, reduced $\mathrm{P}$ fixation and increased $\mathrm{P}$ uptake and increase in $\mathrm{K}$ uptake possibly due to the stimulation effect of silicon on the activation of $\mathrm{H}$ ATPase in the cell membrane. Incorporation of fly ash and organic manures recorded higher $\mathrm{N}$, P, and $\mathrm{K}$ uptake by rice was reported by Mittra et al. (2003).

\section{C.Soil properties}

The addition co composts alone or with graded dose of lignite fly ash significantly improved water stable aggregates, moisture retentive capacity and reduced bulk density compared to initial soil across all crops (table 3). The improvement in water stable aggregates and moisture retentive capacity and reduction in bulk density was more visible in the presence of lignite fly ash. In the studies reporting a reduction in bulk densities, the most common explanation was that the OM increased the void spaces leading to a decrease in the bulk density. Layman (2010) described this phenomenon as the "fluff" effect on soil bulk density as OM has a lower density than the mineral fraction of soil. Compost is known to have a high-water holding capacity and can provide water to plants over time (Crogger, 2005). Aggelides and Londra (2000) compared water retention with different rates of a mixed source compost incorporated $15 \mathrm{~cm}$ into a clay and loam soil. They found increased water retention with higher compost rates in both the clay and loam soil. Compost increased large pores especially the pores holding water at around $5 \mathrm{kPa}$ tension for water retention. The clay soil tended to have higher water contents values at all pressures compared to the loam soil. This was observed in the present study, moisture retention in rice and maize soil was higher than groundnut and brinjal soil by virtue of being clay loam soil compared sandy clay loam soil. Improved soil moisture associated with compost is attributable to mulching effect of organic matter and improved moisture retention and water acceptance as a result of improved soil structure and macro porosity (Aluko and Oyedele, 2005). Fly ash addition reduced bulk density of soil, which in turn improved soil porosity and workability and enhanced water retention capacity (Sharma and Kalra, 2006).

\section{ACKNOWLEDGEMENTS}

The authors profusely thank the Ministry of Environment, Forests and climate change, New Delhi for the financial assistance provided by them.

\section{REFERENCES}

1. Aggelides, S M and Londra P A, Effects of compost produced from town wastes and sewage sludge on the physical properties of a loamy and a clay soil. Bioresour. Technol., 2000, 253-259.

2. Aluko O B and Oyedele D J, Influence of organic incorporation on changes in selected soil physical properties during drying of a Nigerian Alfisols. J. of Applied Sci. 2005, 5:357-362.

3. Aziz T, Samiullah SA, Nasim M, Farooq M and Khan M M, Nutrient availability and maize growth in soil amended with organic manure. Int J Agric Biol , 2010, 12(4):621-624.

4. Crogger C G, Potential compost benefits for restoration of soils disturbed by urban development. Compost Sci. Util. 2005, 13, 243-251. 
ISSN: 2581-8341

Volume 04 Issue 10 October 2021

DOI: 10.47191/ijcsrr/V4-i10-06, Impact Factor: 5.825

5. Donn S, Wheatley R E, McKenzie B M, Loades K W, and Hallett P D, Improved soil fertility from compost amendment increases root growth and reinforcement of surface soil on slope. Ecol. Eng. 2014, 71:458-465

6. Gul S, Naz A, Khan A, Nisa S, and Irshad M. Phytoavailability and leachability of heavy metals from contaminated soil treated with composted livestock manure. Soil Sediment Contam 2016,25:181-194.

7. Irshad M, Gul S, Eneji A E, Anwar Z, and Ashraf M . Extraction of heavy metals from manure and their bioavailability to spinach after composting. J Plant Nutr , 2014, 37:1661-1675.

8. Irshad M, Yamamoto S, Eneji A E, Honna T, and Endo T. Influence of composted manure and salinity on growth and nutrient content of maize tissue. Sand Dune Res, 2002, 49:1-10

9. Jala, S and Goyal. D. Fly ash as a soil ameliorant for improving crop production-a review. Bioresour. Techno., 2006, 97:1136-1147.

10. Layman R M, Rehabilitation of Severely Compacted Urban Soil to Improve Tree Establishment and Growth Rachel Montgomery Layman. MS Thesis. Department of Crop and Environmental Soil Sciences. Virginia Polytechnic Institute and State University, Blacksburg, VA.

11. Malhi SS Relative effectiveness of various amendments in improving yield and nutrient uptake under organic crop production. Open J Soil Sci , 2012, 2:299-311.

12. Mittra, B N, Karmakar S, Swain D K, and Ghosh B C. Fly Ash - A potential source of soil amendment and a component of integrated plant nutrient supply system. International Ash Utilization Symposium, Center for Applied Energy Research, University of Kentucky., 2003, 28.

13. Nadjet M, Abderezzak D, and Meriem K H. Effect of three types of composts of olive oil by-products on growth and yield of hard wheat "Triticum durum Desf.". Afr J Biotechnol, 2014, 13(52):4685-4693

14. Pampuro N, Dinuccio E, Balsari P, and Cavallo E . Evaluation of two composting strategies for making pig slurry solid fraction suitable for pelletizing. Atmos Pollut Res, 2016, 7:288-293

15. Rautaray, S K, Ghosh B C, and Mittra B N .Effect of fly ash, organic wastes and chemical fertilizers on yield, nutrient uptake, heavy metal content and residual fertility in a rice-mustard cropping sequence under acid lateritic Soils. Bioresour. Techno., 2013, 90(3):275-283.

16. Scotti R, Ascoli D R, Bonanomi G, Caceres MG, Sultana S, Cozzolino L, Scelza R, Zoina A, and Rao M A. Combined use of compost and wood scraps to increase carbon stock and improve soil quality in intensive farming systems. Eur. J Soil Sci 2015. https://doi.org/10.1111/ejss. 12248

17. Sharma SK and Kalra N. Effect of fly ash incorporation on soil properties and productivity of crops: A Rev. J. Sci. Indust. Res., 2006, 65: 383-390.

18. Tejada M, Hernandez M T, and Garcia C. Soil restoration using composted plant residues: Effects on soil properties, Soil Till. Res. 2009, 102, 109-117.

19. Wells A T, Chan K Y, and Cornish, P S. Comparison of conventional and alternative vegetable farming systems on the properties o a yellow earth in New South Wales. Agri. Eco. and Environ., 2000, 80 (1-2), 47-60 
International Journal of Current Science Research and Review

ISSN: 2581-8341

Volume 04 Issue 10 October 2021

DOI: 10.47191/ijcsrr/V4-i10-06, Impact Factor: 5.825

IJCSRR @ 2021

www.ijjcsrr.org

Table I. Effect of Co-Compost and Lignite Fly Ash on Yield of Crops

\begin{tabular}{|c|c|c|c|c|c|c|c|}
\hline \multirow{2}{*}{ Treatments } & \multicolumn{2}{|c|}{ Rice ( $\mathrm{kg} / \mathrm{ha})$} & \multicolumn{2}{|c|}{ Maize( kg/ha) } & \multicolumn{2}{|c|}{ Groundnut( $\mathrm{kg} / \mathrm{ha})$} & \multirow{2}{*}{$\begin{array}{l}\text { Brinja } \\
\text { (t/ha) }\end{array}$} \\
\hline & Grain & Straw & Grain & Straw & Pod & Haulm & \\
\hline $\mathrm{T}_{1}-\mathrm{DFW}+\mathrm{CR}$ & 5175 & 6750 & 4520 & 7610 & 2270 & 3110 & 19.23 \\
\hline $\begin{array}{l}\mathrm{T}_{2^{-}} \\
\mathrm{PM}+\mathrm{CR}\end{array}$ & 5250 & 6875 & 4600 & 7950 & 2300 & 3180 & 20.06 \\
\hline $\begin{array}{l}\mathrm{T}_{3^{-}} \\
\mathrm{DFW}+\mathrm{CR}+ \\
5 \mathrm{t} / \mathrm{ha} \mathrm{LFA}\end{array}$ & 5900 & 7525 & 5070 & 8920 & 2568 & 3456 & 21.95 \\
\hline $\begin{array}{l}\mathrm{T}_{4^{-}} \\
\text {DFW+CR+ } \\
\text { t/ha LFA }\end{array}$ & 6500 & 7950 & 5580 & 9590 & 2882 & 3755 & 25.12 \\
\hline $\begin{array}{l}\mathrm{T}_{5^{-}} \\
\mathrm{DFW}+\mathrm{CR}+ \\
15 \mathrm{t} / \mathrm{ha} \mathrm{LFA}\end{array}$ & 6600 & 7975 & 5630 & 9820 & 2980 & 3860 & 25.84 \\
\hline $\begin{array}{l}\mathrm{T}_{6^{-}} \\
\mathrm{PM}+\mathrm{CR}+ \\
5 \mathrm{t} / \mathrm{ha} \mathrm{LFA}\end{array}$ & 6200 & 7675 & 5100 & 9070 & 2600 & 3495 & 25.18 \\
\hline $\begin{array}{l}\mathrm{T}_{7^{-}} \\
\mathrm{PM}+\mathrm{CR}+ \\
10 \mathrm{t} / \mathrm{ha} \mathrm{LFA}\end{array}$ & 6750 & 8425 & 5770 & 9850 & 2964 & 3800 & 27.94 \\
\hline $\begin{array}{l}\mathrm{T}_{8^{-}} \\
\mathrm{PM}+\mathrm{CR}+ \\
15 \mathrm{t} / \mathrm{ha} \text { LFA }\end{array}$ & 6775 & 8475 & 5800 & 9940 & 3025 & 3882 & 28.87 \\
\hline $\mathrm{SE}_{\mathrm{d}}$ & 21.9 & 24.6 & 80 & 150 & 57.0 & 65.0 & 0.94 \\
\hline CD@5\% & 60.4 & 68.0 & 220 & 430 & 157.3 & 179.4 & 2.60 \\
\hline
\end{tabular}

Table II. Effect of Co-Compost and Lignite Fly Ash on Nutrient Uptake by Crops

\begin{tabular}{|c|c|c|c|c|c|c|c|c|c|c|c|c|c|c|}
\hline \multirow[b]{2}{*}{ Treatments } & \multicolumn{4}{|c|}{ Rice } & \multicolumn{3}{|c|}{ Maize } & \multicolumn{4}{|c|}{ Groundnut } & \multicolumn{3}{|c|}{ Brinjal } \\
\hline & $\mathrm{N}$ & $\mathrm{P}$ & $\mathrm{K}$ & $\mathrm{S}$ & $\mathrm{P}$ & $\mathrm{K}$ & $\mathrm{S}$ & $\mathrm{P}$ & $\mathrm{K}$ & $\mathrm{S}$ & $\mathrm{Ca}$ & $\mathrm{P}$ & $\mathrm{K}$ & $S$ \\
\hline $\begin{array}{l}\mathrm{T}_{1^{-}} \\
\mathrm{DFW}+\mathrm{CR}\end{array}$ & 114 & $\begin{array}{c}22 \\
.9\end{array}$ & $\begin{array}{l}12 \\
3\end{array}$ & $\begin{array}{l}8 . \\
95\end{array}$ & $\begin{array}{l}37 . \\
4\end{array}$ & $\begin{array}{l}14 \\
5\end{array}$ & $\begin{array}{l}13 . \\
0\end{array}$ & $\begin{array}{l}18 . \\
2\end{array}$ & 96.2 & $\begin{array}{l}16 . \\
4\end{array}$ & $\begin{array}{l}39 . \\
8\end{array}$ & 8.3 & $\begin{array}{l}18 . \\
2\end{array}$ & 7.1 \\
\hline $\begin{array}{l}\mathrm{T}_{2^{-}} \\
\mathrm{PM}+\mathrm{CR}\end{array}$ & 118 & $\begin{array}{l}29 \\
.3\end{array}$ & $\begin{array}{l}13 \\
8\end{array}$ & $\begin{array}{l}11 \\
.3\end{array}$ & $\begin{array}{l}40 . \\
7\end{array}$ & $\begin{array}{l}14 \\
9\end{array}$ & $\begin{array}{l}14 . \\
4\end{array}$ & $\begin{array}{l}24 . \\
0\end{array}$ & $\begin{array}{l}103 . \\
1\end{array}$ & $\begin{array}{l}18 . \\
7\end{array}$ & $\begin{array}{l}42 . \\
4\end{array}$ & $\begin{array}{l}10 . \\
6\end{array}$ & $\begin{array}{l}21 . \\
6\end{array}$ & 8.6 \\
\hline $\begin{array}{l}\mathrm{T}_{3^{-}} \\
\mathrm{DFW}+\mathrm{CR} \\
+ \\
5 \text { t/ha LFA }\end{array}$ & 112 & $\begin{array}{l}25 \\
.2\end{array}$ & $\begin{array}{l}12 \\
8\end{array}$ & $\begin{array}{l}11 \\
.2\end{array}$ & $\begin{array}{l}42 . \\
2\end{array}$ & $\begin{array}{l}15 \\
0\end{array}$ & $\begin{array}{l}14 . \\
3\end{array}$ & $\begin{array}{l}22 . \\
4\end{array}$ & $\begin{array}{l}101 . \\
7\end{array}$ & $\begin{array}{l}20 . \\
6\end{array}$ & $\begin{array}{l}41 . \\
7\end{array}$ & $\begin{array}{l}10 . \\
7\end{array}$ & $\begin{array}{l}20 . \\
5\end{array}$ & 8.8 \\
\hline $\begin{array}{l}\mathrm{T}_{4^{-}} \\
\mathrm{DFW}+\mathrm{CR} \\
+10 \mathrm{t} / \mathrm{ha} \\
\mathrm{LFA}\end{array}$ & 114 & $\begin{array}{l}31 \\
.0\end{array}$ & $\begin{array}{l}13 \\
5\end{array}$ & $\begin{array}{l}13 \\
.8\end{array}$ & $\begin{array}{l}47 . \\
0\end{array}$ & $\begin{array}{l}15 \\
5\end{array}$ & $\begin{array}{l}15 . \\
8\end{array}$ & $\begin{array}{l}27 . \\
5\end{array}$ & $\begin{array}{l}107 . \\
8\end{array}$ & $\begin{array}{l}24 . \\
8\end{array}$ & $\begin{array}{l}43 . \\
5\end{array}$ & $\begin{array}{l}13 . \\
4\end{array}$ & $\begin{array}{l}22 . \\
9\end{array}$ & $\begin{array}{l}10 . \\
5\end{array}$ \\
\hline $\mathrm{T}_{5^{-}}$ & 117 & $\begin{array}{l}33 \\
.0\end{array}$ & $\begin{array}{l}13 \\
7\end{array}$ & $\begin{array}{c}15 \\
.3\end{array}$ & $\begin{array}{l}48 . \\
7\end{array}$ & $\begin{array}{l}15 \\
7\end{array}$ & $\begin{array}{l}16 . \\
2\end{array}$ & $\begin{array}{l}29 . \\
3\end{array}$ & $\begin{array}{l}109 . \\
5\end{array}$ & $\begin{array}{l}25 . \\
8\end{array}$ & $\begin{array}{l}44 . \\
7\end{array}$ & $\begin{array}{l}14 . \\
1\end{array}$ & $\begin{array}{l}24 . \\
1\end{array}$ & $\begin{array}{l}11 . \\
1\end{array}$ \\
\hline
\end{tabular}


International Journal of Current Science Research and Review

ISSN: 2581-8341

Volume 04 Issue 10 October 2021

DOI: 10.47191/ijcsrr/V4-i10-06, Impact Factor: 5.825

IJCSRR @ 2021

www.ijjcsrr.org

\begin{tabular}{|c|c|c|c|c|c|c|c|c|c|c|c|c|c|c|}
\hline $\begin{array}{l}\text { DFW+CR } \\
+ \\
15 \quad \text { t/ha } \\
\text { LFA }\end{array}$ & & & & & & & & & & & & & & \\
\hline $\begin{array}{l}\mathrm{T}_{6^{-}} \\
\mathrm{PM}+\mathrm{CR}+ \\
5 \mathrm{t} / \mathrm{ha} \mathrm{LFA}\end{array}$ & 123 & $\begin{array}{l}35 \\
.3\end{array}$ & $\begin{array}{l}14 \\
5\end{array}$ & $\begin{array}{l}14 \\
.3\end{array}$ & $\begin{array}{l}46 . \\
5\end{array}$ & $\begin{array}{l}15 \\
4\end{array}$ & $\begin{array}{l}15 . \\
8\end{array}$ & $\begin{array}{l}28 . \\
6\end{array}$ & $\begin{array}{l}108 \\
3\end{array}$ & $\begin{array}{l}23 . \\
6\end{array}$ & $\begin{array}{l}43 . \\
9\end{array}$ & $\begin{array}{l}12 . \\
9\end{array}$ & $\begin{array}{l}23 . \\
9\end{array}$ & $\begin{array}{l}10 . \\
4\end{array}$ \\
\hline $\begin{array}{l}\mathrm{T}_{7-} \\
\mathrm{PM}+\mathrm{CR}+ \\
10 \quad \mathrm{t} / \mathrm{ha} \\
\mathrm{LFA}\end{array}$ & 126 & $\begin{array}{l}42 \\
.3\end{array}$ & $\begin{array}{l}15 \\
2\end{array}$ & $\begin{array}{l}18 \\
.2\end{array}$ & $\begin{array}{l}52 . \\
4\end{array}$ & $\begin{array}{l}15 \\
9\end{array}$ & $\begin{array}{l}17 . \\
1\end{array}$ & $\begin{array}{l}34 . \\
1\end{array}$ & $\begin{array}{l}113 . \\
7\end{array}$ & $\begin{array}{l}28 . \\
3\end{array}$ & $\begin{array}{l}45 . \\
9\end{array}$ & $\begin{array}{l}15 . \\
4\end{array}$ & $\begin{array}{l}26 . \\
4\end{array}$ & $\begin{array}{l}12 . \\
0\end{array}$ \\
\hline $\begin{array}{l}\mathrm{T}_{8^{-}} \\
\mathrm{PM}+\mathrm{CR}+ \\
15 \quad \mathrm{t} / \mathrm{ha} \\
\mathrm{LFA}\end{array}$ & 128 & $\begin{array}{l}44 \\
.0\end{array}$ & $\begin{array}{l}15 \\
4\end{array}$ & $\begin{array}{l}19 \\
.4\end{array}$ & $\begin{array}{l}55 . \\
1\end{array}$ & $\begin{array}{l}16 \\
1\end{array}$ & $\begin{array}{l}17 . \\
6\end{array}$ & $\begin{array}{l}36 . \\
8\end{array}$ & $\begin{array}{l}115 . \\
9\end{array}$ & $\begin{array}{l}29 . \\
9\end{array}$ & $\begin{array}{l}46 . \\
9\end{array}$ & $\begin{array}{l}16 . \\
5\end{array}$ & $\begin{array}{l}27 . \\
5\end{array}$ & $\begin{array}{l}12 . \\
7\end{array}$ \\
\hline $\mathrm{SE}_{\mathrm{d}}$ & 1.66 & $\begin{array}{l}1 . \\
7\end{array}$ & $\begin{array}{l}1 . \\
8\end{array}$ & $\begin{array}{l}0 . \\
7\end{array}$ & 1.6 & 1.6 & 0.4 & 1.9 & 2.4 & 1.9 & 0.5 & 0.8 & 0.6 & 0.6 \\
\hline CD@5\% & 4.60 & $\begin{array}{l}4 . \\
6\end{array}$ & $\begin{array}{l}5 . \\
2\end{array}$ & $\begin{array}{l}2 . \\
0\end{array}$ & 4.3 & 4.4 & 1.0 & 5.1 & 6.7 & 5.4 & 1.3 & 2.2 & 1.6 & 1.6 \\
\hline
\end{tabular}

Table III. Effect of Co-Compost and Lignite Fly Ash on Physical Properties

\begin{tabular}{|c|c|c|c|c|c|c|c|c|c|c|c|c|}
\hline \multirow[b]{2}{*}{$\begin{array}{l}\text { Treat } \\
\text { ments }\end{array}$} & \multicolumn{3}{|l|}{ Rice } & \multicolumn{3}{|l|}{ Maize } & \multicolumn{3}{|c|}{ Groundnut } & \multicolumn{3}{|l|}{ Brinjal } \\
\hline & $\begin{array}{l}\text { Water } \\
\text { Stable } \\
\text { Aggre } \\
\text { gates } \\
(> \\
0.25 \mathrm{~m} \\
\mathrm{~m} \\
\text { size) }\end{array}$ & $\begin{array}{l}\text { Mois } \\
\text { ture } \\
\text { reten } \\
\text { tive } \\
\text { capa } \\
\text { city } \\
(\%)\end{array}$ & $\begin{array}{l}\text { Bul } \\
\mathrm{k} \\
\text { Den } \\
\text { sity } \\
(\mathrm{Mg} \\
\mathrm{m}^{-3} \\
)\end{array}$ & $\begin{array}{l}\text { Water } \\
\text { Stable } \\
\text { Aggre } \\
\text { gates } \\
(> \\
0.25 \mathrm{~m} \\
\mathrm{~m} \\
\text { size) }\end{array}$ & $\begin{array}{l}\text { Mois } \\
\text { ture } \\
\text { reten } \\
\text { tive } \\
\text { capa } \\
\text { city } \\
(\%)\end{array}$ & $\begin{array}{l}\text { Bul } \\
\mathrm{k} \\
\text { Den } \\
\text { sity } \\
(\mathrm{Mg} \\
\mathrm{m}^{-3} \\
)^{3}\end{array}$ & $\begin{array}{l}\text { Water } \\
\text { Stable } \\
\text { Aggre } \\
\text { gates } \\
(> \\
0.25 \mathrm{~m} \\
\mathrm{~m} \\
\text { size })\end{array}$ & $\begin{array}{l}\text { Mois } \\
\text { ture } \\
\text { reten } \\
\text { tive } \\
\text { capa } \\
\text { city } \\
(\%)\end{array}$ & $\begin{array}{l}\text { Bul } \\
\mathrm{k} \\
\text { Den } \\
\text { sity } \\
(\mathrm{Mg} \\
\mathrm{m}^{-3} \\
)\end{array}$ & $\begin{array}{l}\text { Water } \\
\text { Stable } \\
\text { Aggre } \\
\text { gates } \\
(> \\
0.25 \mathrm{~m} \\
\mathrm{~m} \\
\text { size) }\end{array}$ & $\begin{array}{l}\text { Mois } \\
\text { ture } \\
\text { reten } \\
\text { tive } \\
\text { capa } \\
\text { city } \\
(\%)\end{array}$ & $\begin{array}{l}\text { Bul } \\
\mathrm{k} \\
\text { Den } \\
\text { sity } \\
(\mathrm{Mg} \\
\mathrm{m}^{-3} \\
)\end{array}$ \\
\hline $\begin{array}{l}\mathrm{T}_{1}- \\
\mathrm{DFW}+ \\
\mathrm{CR}\end{array}$ & 44.8 & 60.6 & 1.46 & 43.2 & 53.2 & 1.37 & 40.4 & 40.3 & 1.40 & 37.3 & 35.5 & 1.43 \\
\hline $\begin{array}{l}\mathrm{T}_{2^{-}} \\
\mathrm{PM}+\mathrm{C} \\
\mathrm{R}\end{array}$ & 49.2 & 63.4 & 1.44 & 45.5 & 55.3 & 1.33 & 40.9 & 41.8 & 1.32 & 39.4 & 37.2 & 1.40 \\
\hline $\begin{array}{l}\mathrm{T}_{3^{-}} \\
\mathrm{DFW}+ \\
\mathrm{CR}+ \\
5 \mathrm{t} / \mathrm{ha} \\
\mathrm{LFA}\end{array}$ & 47.9 & 63.0 & 1.45 & 45.6 & 55.5 & 1.32 & 43.0 & 42.9 & 1.31 & 40.1 & 38.1 & 1.40 \\
\hline $\begin{array}{l}\mathrm{T}_{4^{-}} \\
\mathrm{DFW}+ \\
\mathrm{CR}+ \\
10\end{array}$ & 51.6 & 65.8 & 1.41 & 47.9 & 57.4 & 1.28 & 45.9 & 45.5 & 1.22 & 43.2 & 41.3 & 1.33 \\
\hline
\end{tabular}


International Journal of Current Science Research and Review

ISSN: 2581-8341

Volume 04 Issue 10 October 2021

DOI: 10.47191/ijcsrr/V4-i10-06, Impact Factor: 5.825

IJCSRR @ 2021

www.ijjcsrr.org

\begin{tabular}{|c|c|c|c|c|c|c|c|c|c|c|c|c|}
\hline $\begin{array}{l}\text { t/ha } \\
\text { LFA }\end{array}$ & & & & & & & & & & & & \\
\hline $\begin{array}{l}\mathrm{T}_{5^{-}} \\
\mathrm{DFW}+ \\
\mathrm{CR}+ \\
15 \\
\mathrm{t} / \mathrm{ha} \\
\mathrm{LFA}\end{array}$ & 52.8 & 66.4 & 1.39 & 48.3 & 57.9 & 1.27 & 46.7 & 46.6 & 1.18 & 44.5 & 42.6 & 1.25 \\
\hline $\begin{array}{l}\mathrm{T}_{6^{-}} \\
\mathrm{PM}+\mathrm{C} \\
\mathrm{R}+ \\
5 \mathrm{t} / \mathrm{ha} \\
\mathrm{LFA}\end{array}$ & 53.6 & 66.0 & 1.41 & 47.8 & 57.6 & 1.29 & 44.4 & 44.7 & 1.22 & 43.1 & 39.9 & 1.32 \\
\hline $\begin{array}{l}\mathrm{T}_{7^{-}} \\
\mathrm{PM}+\mathrm{C} \\
\mathrm{R}+ \\
10 \\
\mathrm{t} / \mathrm{ha} \\
\mathrm{LFA}\end{array}$ & 56.8 & 68.8 & 1.36 & 50.4 & 59.5 & 1.25 & 47.5 & 47.8 & 1.13 & 46.3 & 42.8 & 1.25 \\
\hline $\begin{array}{l}\mathrm{T}_{8^{-}} \\
\mathrm{PM}+\mathrm{C} \\
\mathrm{R}+ \\
15 \\
\mathrm{t} / \mathrm{ha} \\
\mathrm{LFA}\end{array}$ & 57.9 & 69.6 & 1.35 & 50.7 & 60.1 & 1.24 & 48.2 & 48.6 & 1.09 & 47.4 & 43.7 & 1.18 \\
\hline $\mathrm{SE}_{\mathrm{d}}$ & 0.9 & 0.8 & 0.02 & 0.8 & 0.7 & 0.01 & 0.9 & 0.9 & 0.03 & 0.9 & 0.9 & 0.02 \\
\hline $\begin{array}{l}\mathrm{CD} @ \\
5 \%\end{array}$ & 2.6 & 2.2 & 0.04 & 2.2 & 1.8 & 0.04 & 2.5 & 2.4 & 0.07 & 2.7 & 2.4 & 0.06 \\
\hline
\end{tabular}

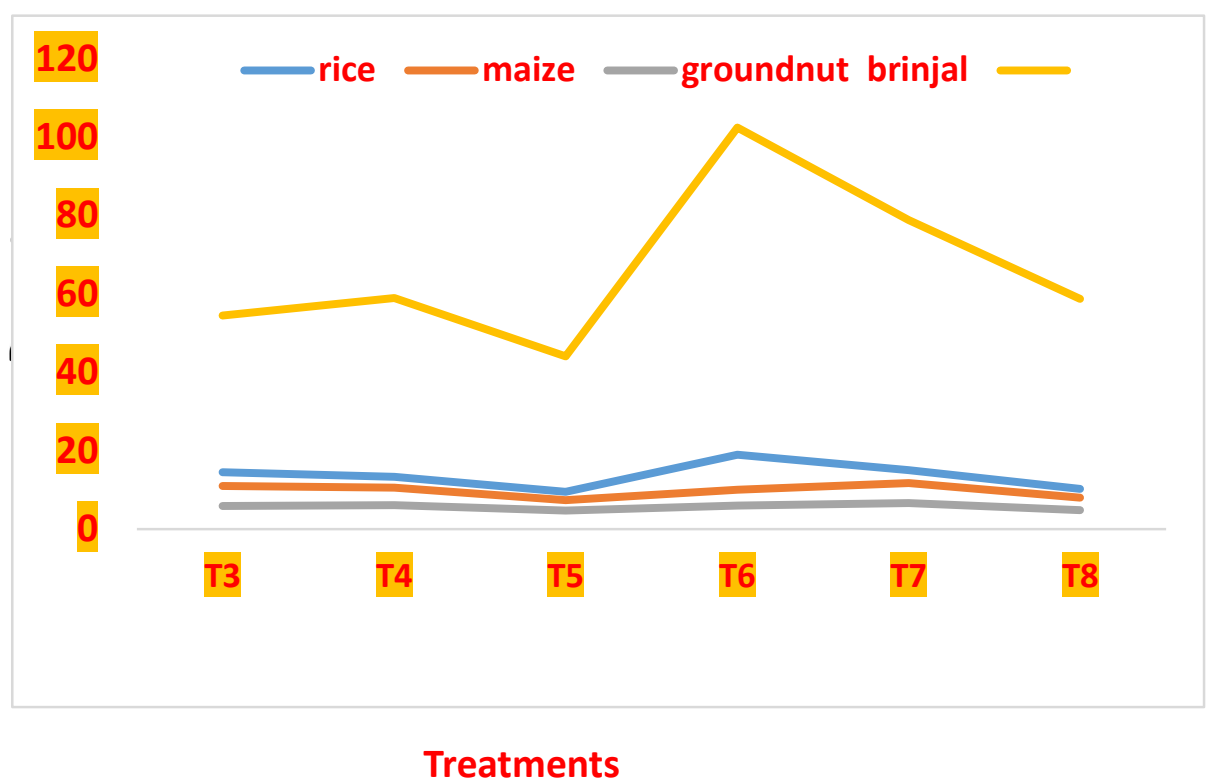

Fig.1. Percent increase in yield of crops due to Lignite fly ash and co compost over co compost alone 


\section{International Journal of Current Science Research and Review}

ISSN: 2581-8341

Volume 04 Issue 10 October 2021

DOI: 10.47191/ijesrr/V4-i10-06, Impact Factor: 5.825

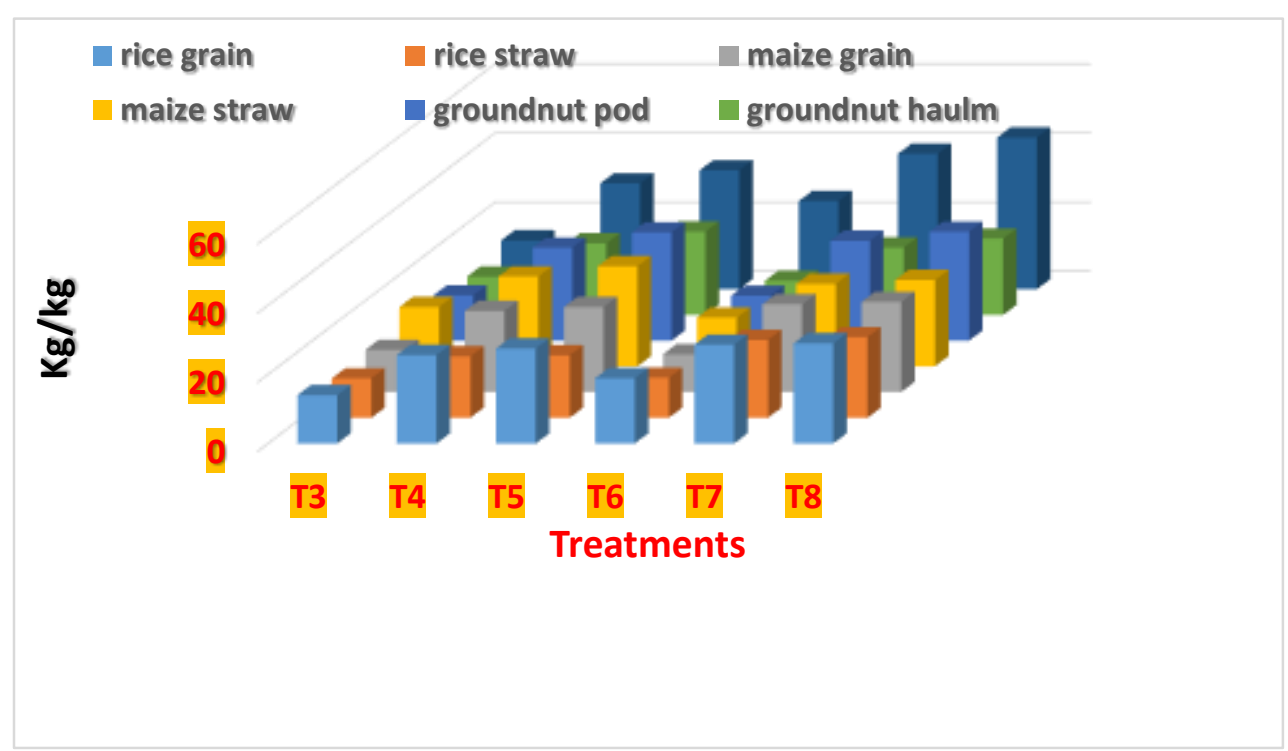

Fig.2. Effect of lignite fly ash and co compost on agronomic efficiency of crops

Cite this Article: Angayarkanni, A, M.V. Sriramachandrasekharan, M. Salahuddin, P. Poonkodi (2021). Integrated Use of Co Compost with Lignite Fly Ash on Yield and Nutrient Uptake of Certain Crops. International Journal of Current Science Research and Review, 4(10), 1229-1236 